University of Nebraska - Lincoln

DigitalCommons@University of Nebraska - Lincoln

6-1922

\title{
Variations in Cytology and Gross Morphology of Taraxacum II. Senescence, Rejuvenescence, and Leaf Variation in Taraxacum
}

Paul Sears

University of Nebraska - Lincoln

Follow this and additional works at: https://digitalcommons.unl.edu/biosciecology

Part of the Ecology and Evolutionary Biology Commons

Sears, Paul, "Variations in Cytology and Gross Morphology of Taraxacum II. Senescence, Rejuvenescence, and Leaf Variation in Taraxacum" (1922). Papers in Ecology. 15.

https://digitalcommons.unl.edu/biosciecology/15

This Article is brought to you for free and open access by the Papers in the Biological Sciences at DigitalCommons@University of Nebraska - Lincoln. It has been accepted for inclusion in Papers in Ecology by an authorized administrator of DigitalCommons@University of Nebraska - Lincoln. 


\section{THE \\ BOTANICAL GAZETTE}

Fune 1922

\section{VARIATIONS IN CYTOLOGY AND GROSS MORPHOLOGY OF TARAXACUM}

II. SENESCENCE, REJUVENESCENCE, AND LEAF VARIATION IN TARAXACUM

CONTRIBUTIONS FROM THE HULL BOTANICAL LABORATORY 295

PAUL BIGELOW SEARS

(WITH NINE FIGURES)

The variability of Taraxacum has frequently been recorded in botanical literature without receiving much elucidation. It is less often an object of investigation than of conjecture and discussion. A few botanists have studied the effect of environmental factors upon Taraxacum, but their results have not cleared away taxonomic difficulties. Systematic botanists have either looked upon the variations in this genus as fluctuations or slight mutations, and then proceeded to lump or split as judgment might dictate. That life history exerts a profound influence upon form seems generally to have escaped attention.

The I910 supplement of Index Kewensis (12) lists I 52 new species as described within five years, mainly from Scandinavia. Leaving aside such overwhelming evidence of polymorphy, it is interesting to note that the painstaking monograph of HANDEL-MAZETTI (Io) admits fifty-seven species. These fall into eleven sections. Of these eleven sections four are so distinctive that none of their species have been mistaken by preceding students for either $T$. vulgare or $T$. laevigatum. In each of the remaining sections species have 
been confused at various times with one or the other of the familiar species named, and designated accordingly in publications. Beyond question some of this confusion has been due to bad taxonomy. There is ample reason to believe that more of it has been caused by lack of definite boundaries between species.

Although the two common species mentioned are parthenogenetic, sexual species are known and hybrids may exist. Aside from this possibility, any explanations offered for the overlap between species have been so admittedly hypothetical (Io) that they need not be rehearsed at this point. It is necessary, however, to take inventory of the precise information available with respect to variation in Taraxacum and its causes. It is also necessary to examine the nature of the criteria used in differentiating species and species groups.

Rоoт.-Generally referred to as perennial, without modification, it has long been known to branch multicipitally (4), and to split into separate individuals (5).

STEM.-Usually represented only by a growing point; in the absence of light internodes develop (20), giving rise to a vertical rhizome (cf. fig. 4).

LEAvES.-Although taxonomists admit great variability and the frequency of overlap between leaf characters of different species, it is a fact that leaf characters are extensively used in species descriptions and often in distinctions. "Habit" as indicated by leaf orientation is also so used (3), despite a lack of evidence that the light responses of Taraxacum differ from those of other plants. In a saturated atmosphere greatly elongated leaves are produced $(\mathbf{2 0})$. The reverse is true, that dry air shortens the longitudinal components of the leaf, although WIESNER's statement that it slightly increases dissection is open to question. Arctic alpine conditions result in a symmetrical dwarfing of the leaves of transplants (2). Check and transplant in this experiment were of equal age, and show little difference in degree of leaf dissection in BONNIER's original figures. Salt itself is not the direct cause of succulence in leaves of saline soil species of Taraxacum (II). The rate of production of leaves in plants of identical age varies with the habitat, being less in strong sunlight than in shade (2o). 
Handel-Mazetti (Io) notes a marked difference in the rate at which oldest leaves die away and leave their bases, considering it a specific characteristic.

As to segmentation, Goebel (9) classifies Taraxacum with those plants which produce first entire, then dissected leaves, but quotes evidence that segmentation is "richer" in temperate than arctic forms, and in "well-nourished" plants than in "half-starved" meadow-moor forms. DeVARIGNy, as quoted by Morgan (I4), places his own construction upon the matter by attributing the dissection to dry soil conditions and entire leaves to hydrophytic environment. FrANK (8) states that leaf development is basipetal, the tip segment developing first. STORK (I7) found that uniform culture conditions upon seedlings (of identical age) produce rather uniform leaf type, regardless of leaf form extremes in the parents.

SCAPE. - The normal course of changes in length and position. throughout flowering and fruiting are well known (I5). FRANK states that in alpine species the scape is longer in crevice plants than in those growing exposed.

INFLORESCENCE.-Fasciation is admittedly a nonheritable character, and was determined by Schorbatow (I6) to be due to mechanical pressure during the period of most active flowering, "the third year."

BRACTS.-In taxonomic works these rank highly as criteria, the characteristics used being number, color, size, form, and position. Nevertheless, considerable variability is admitted. HANDEL-MAZETTI notes that infection by Synchitrium taraxaci converted the outer bracts of $T$. vulgare into those typical for T. alpinum. He also speaks of the great variation in corniculi in many species. FERNALD (7) found very complete intergrades between $T$. vulgare and $T$. palustre in bracts, as well as other characters. STORK reports that uniform culture conditions produce great uniformity in seedlings from parents with widely different bract characters.

Flowers.-HANDEL-MAZETTI uses approximate flower number as a specific criterion, and states that flower color is undoubtedly a trustworthy character, although us eless in dealing with herbarium 
material. The presence or absence of pollen, used by several Scandinavian authors as a specific character, is considered by the authority just quoted to be highly variable within the species, unless the observations of other men were erroneous.

Achenes.-These are generally regarded as affording the most critical taxonomic characters, that is, in size, form, color, beak length, pappus color, ribbing, and tubercles. Actually size is no more exempt from the laws of fluctuation in Taraxacum than in any plant, while form is subject to considerable modifications by pressure during development. HANDEL-MAZETTI, however, states that uniform culture conditions have less effect upon achene form than upon leaf and bract characters. Colors vary from dark brown to clear green in $T$. officinale according to ScHoRBATow, who states that the two extremes are fixed in inheritance, but whether he includes $T$. laevigatum under the other species is not clear. In STORK's cultures, chosen from parents varying as widely as possible in achene as in other characters, the progeny were either red or gray fruited. Color does not develop until the outer cells die, and in red fruits is due to homogentisic acid which is absent in gray ones (Io). Freezing may prevent its appearance in T. laevigatum (I7). Beak length is notoriously interfered with by injury, whether by freezing or mowing. Pappus color is said by HandeL-Mazetri to be due to diffraction phenomena and not pigment. The small species group characterized by definite pappus color is therefore likely to be a distinct one. Ribbing is due to the number of stereome bundles beneath the epidermis.

Summarizing, it is seen that while bracts and achenes are conceded to afford the critical characters, the leaves are actually given great weight in spite of their variability and the uncertainty concerning its nature. There is also not a little evidence for bract variability. Pappus color seems dependable, and achene color ought to be generally so, barring environmental extremes.

\section{Observations}

METHOD.-Several years of desultory observation in connection with other phases of this work having failed to throw the necessary light upon the problem of leaf variation, it seemed best to conduct 
thorough studies of entire plants excavated from various habitats. After some fifty plants had thus been secured and studied, several hundred additional spud collections were made for confirmatory purposes. Subsequently all conclusions were tested rigorously by field observations extending over a period of fifteen months. By comparison of root development, color and texture of cortical rind, number and nature of withered petiole zones, and general condition of rosette, it was found that the age of a given plant could be told with considerable accuracy. With this technique as a basis, attention was centered upon the development of life history details and leaf form changes.

LIFE HISTORY.-This procedure revealed an intimate connection between leaf variability and life history. The first consideration is that strict accuracy forbids speaking of Taraxacum as a perennial plant without qualification. As stated by StoRk, Taraxacum ordinarily does not bloom the first year. Blossoming occurs freely in both species throughout the second year. At the end of the period of most active flowering (autumn of second year or spring of third) the vigorous production of flower buds forces apart the inner leaves of the original rosette with their axillary growing points. From such growing points arise numerous secondary rosettes. As a rule several of these persist, functioning essentially as new individuals, in spite of their common root connection. Throughout the length of the root each secondary rosette has its own strand of vascular tissue. The individuality of the parent rosette can only be maintained by the cortical tissues, and these rather generally become cleft by fission and cork ingrowth. Observation indicates that such cleavage is hastened by conditions favoring rapid growth. Cleavage tends to become complete throughout the root length.

LEAF FORM.-The relations between this life history and leaf form is intimate and direct. The first leaves of a seedling (juvenile leaves) tend to be entire and smooth (fig. I), later becoming more dissected and generally more hairy (fig. 2). In T. laevigatum this dissection in general reaches a higher degree than in $T$. vulgare, although the latter species, under conditions favoring luxuriant growth and numerous leaves, finally may attain an extreme degree 
of dissection. When multicipital branching occurs, the new secondary rosettes consist of leaves of juvenile form, that is, tending to be smooth and entire (fig. 3). Each daughter rosette which persists then repeats the history of the parent rosette with respect to leaf form, as well as with respect to flowering habits and eventual

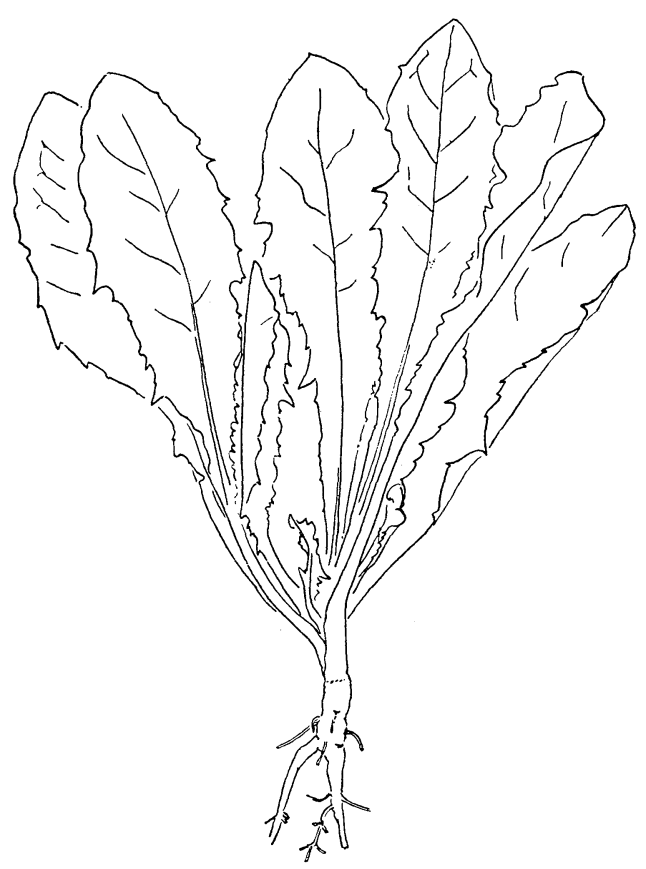

FIG. I

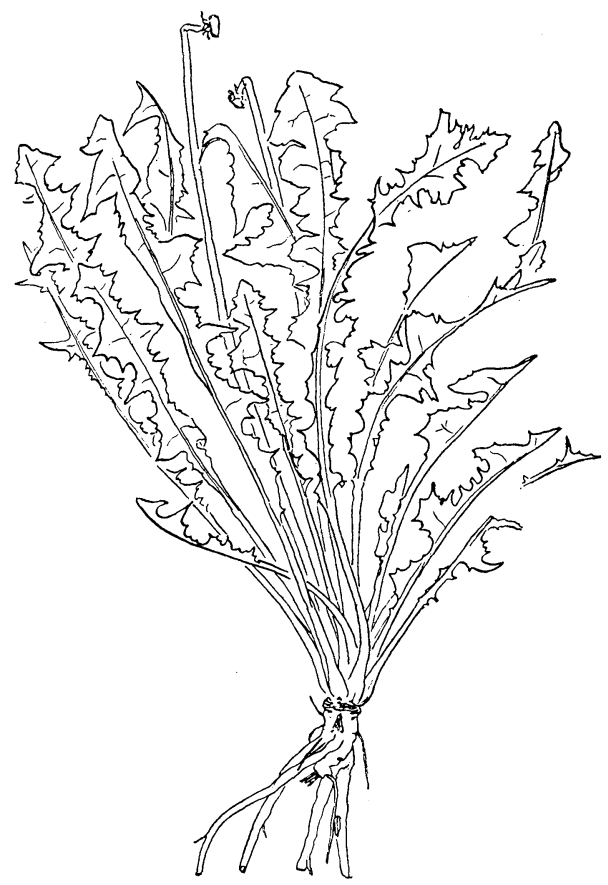

FIG. 2

FIGS. I, 2.-Fig. I, young seedling showing relatively entire leaf form and unbranched crown; fig. 2, seedling at end of flowering period showing highly dissected leaf form, scars of juvenile leaves of first year, and beginnings of root fission.

rejuvenation (fig. 4). Certain modifying factors must be considered. For example, the supply of reserve food in rejuvenating roots results in rosettes that are often unusually vigorous and decidedly different in appearance from seedlings of the same degree of leaf dissection. Again, it not infrequently happens that secondary rosettes on the same root are of different ages, and hence different leaf form (fig. 4). This is bound to confuse an observer who does not excavate the plant and inspect it carefully. 
In the next place, Taraxacum fruits are produced throughout the growing season and germinate readily. Very early spring seedlings may be ready to bloom before frost, and then resume blooming the following spring, equipped with highly dissected leaves. Later seedlings will not bloom until the following spring,

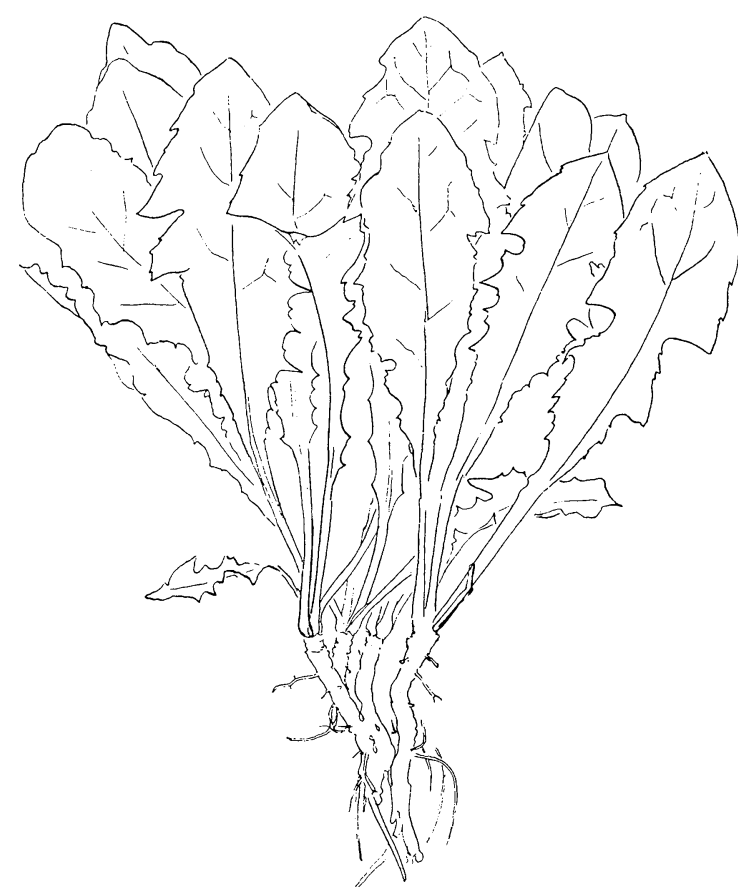

FIG. 3

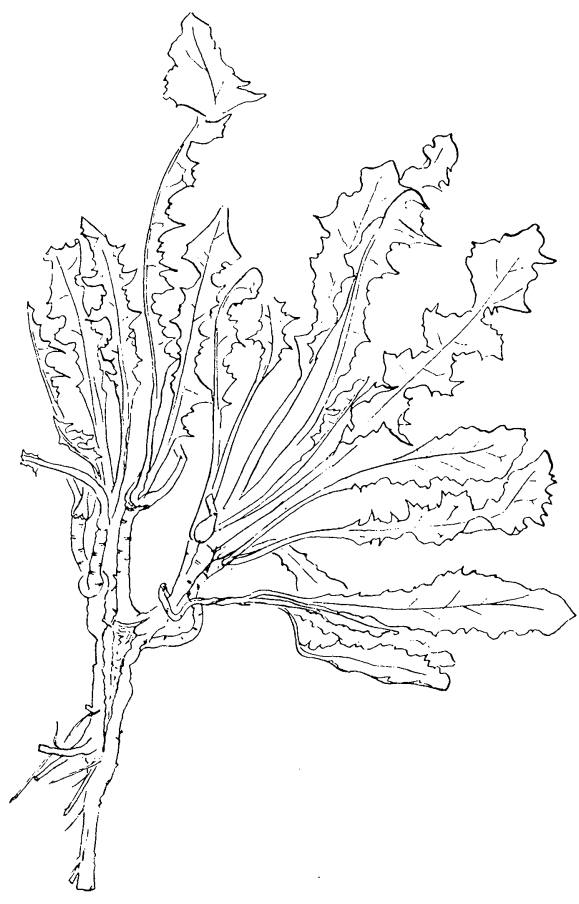

FIg. 4

FIGS. 3, 4.-Fig. 3, plant during first season following rejuvenation, showing juvenile leaf form on each secondary rosette; degree of root fission rather unusual; fig. 4, rejuvenation of buried rrown, showing formation of vertical rhizomes (note leaf scars), which secondary thickening will transform into roots; note presence of rosettes of second year (leaves highly dissected) and of first year (leaves entire).

beginning with somewhat less dissected leaves. Fall seedlings frequently seem to start blooming the next spring with almost entire leaves. In other words, the winter rest period permits many young plants to bloom which would otherwise require a greater degree of maturity or senescence.

The same relations hold true of rejuvenated plants. Secondary rosettes which have started early begin blooming the following 
spring with very much segmented leaves. Those started late in the year begin to bloom the next spring with nearly entire leaves. It is not inconceivable that $T$. palustre consists of vigorous secondary rosettes of $T$. vulgare which have rejuvenated in autumn, or for some other reason flowered in more juvenile condition than usual. If occasional pure stands of such a type are to be found, it may even be suspected that ecological conditions there favor fall germination and establishment of Taraxacum and fall rejuvenation as a consequence. More or less entire-leaved forms, whether regarded as distinct species, varieties, or ecological forms of $T$. vulgare, are generally arctic, alpine, or temperate hydrophytic. None of these habitats favors very early spring germination or long growing season before blooming the second year.

Another source of modification comes during good growing weather in the case of plants that have completed their flowering cycle. Rejuvenation by multicipital branching occurs before the last flower scapes are gone, giving a combination of juvenile leaves with the scapes which characterize senescence. The senescent leaves, present before rejuvenation, very rapidly die and decay. This circumstance, that early leaves die as new ones are produced, is an important one. The plant thus rapidly loosens the bond connecting it with the earlier condition, resulting in an isolation of pseudotypes which are really transient phases.

Field observations have successfully applied WIEsNeR's finding of the effect of moist and dry atmosphere, while experiments have verified the truth of it. The effect of a xerophytic habitat is not to increase the amount of dissection, but to shorten leaves at all stages of senescence. Juvenile leaves become nearly orbicular, whereas they may be almost spatulate in a habitat with low transpiration. Senescent leaves in a xerophytic habitat are so shortened that lobes and incisions become sharply triangular. Senescent leaves in a non-xerophytic habitat are much more graceful and very different in appearance.

ACHENES.-Aside from the failure of red pigment to develop in injured fruits of $T$. laevigatum, achene color seems to be rather a fundamental character, varying in degree but not in kind. Homogentisic acid is a highly specific substance derived from tyrosin, and neither was found in non-red fruits, according to HANDEL- 
Mazetri, already quoted. As to details of achene form, it is possible to find in a field of $T$. vulgare and $T$. laevigatum achenes varying from nearly smooth to almost shaggy. As a rule the form seems consistent in the individual plant.

FLOWERS.-Color is markedly influenced by pigmentation of styles as well as of petals, and by presence or absence of ripe pollen. That flower number per head may not always be relied upon as a criterion becomes evident from field studies. Depauperate plants whose species is unquestionable may produce a surprisingly small number, as few as fifty.

Pollen.-In the spring of I92 I at Lincoln, Nebraska, pollenless plants, both red and gray fruited, were found, the former in abundance. Microscopic examination showed that pollen development had been arrested before the grains had separated. Certain interesting correlations were noted in the red fruited pollenless forms. The leaves are invariably dissected less than the maximum for $T$. laevigatum, and the inner bracts are twelve or thirteen in number, containing in all eighteen to twenty-two corniculi on their greenish tips. It was at first believed that this represents a distinct genetic type, and such indeed may be the case. Search revealed a number of transitional forms, however, with scant pollen, fifteen to eighteen reddish bracts, and leaves considerably dissected. $T$. laevigatum itself has copious pollen, eighteen to twenty red tipped bracts each bearing a corniculus, and leaves heavily dissected. In one case a combination of the two extremes was obtained on different rosettes of the same old root. Quantitative studies, quoted by the courtesy of Mr. H. Pegler, show that the degree of leaf dissection in the pollenless forms increases as one passes from peripheral to central leaves, and lies exactly between the increasing dissection of a young seedling of $T$. laevigatum and the fluctuating dissection of a typical adult of the same species. It is not unlikely, therefore, that this is even a more interesting case of isolation of pseudotype than is the $T$. palustre form of T. vulgare.

Bracts.-Aside from the case just described, bracts of both species have been found to vary notably in the degree of development of the corniculi, in number between twelve and twenty-two, and in color. 
Regeneration.-Mere removal of older competing leaves does not alter the degree of senescent dissection of those subsequently produced. Removal of all leaf incepts, down to undifferentiated meristem, results in production of juvenile leaves. The rhizomes produced by etiolation produce juvenile leaves when cut and placed in a moist chamber; in fact, after secondary thickening begins, pressure crushes the pith, and all rhizomes become essentially roots. Study of developing leaves shows that the juvenile leaves are produced by a disproportionate development of tip segment at the expense of the rest, while dissected leaves result from a more or less uniform development of all segments.

\section{Quantitative studies}

MethoD.-More precise analysis of the rôle of senescence as a cause of leaf dissection being desired, quantitative verification of these observations was obtained from studies of plants growing under widely different natural conditions. Prints of each successive leaf in each rosette studied were outlined by bounding polygons, and area of both leaf and polygon taken by means of a planimeter. The real area of each leaf was then divided into the difference between real and ideal (polygon) area. This, it will be seen, gives a percentage expression for the degree of dissection of each leaf.

It was finally deemed necessary, in order properly to delimit the problem, to investigate some of the correlations which more obviously suggested themselves. On the whole, these center about various phases of conductive efficiency of the xylem. Root cross-sections at various levels were studied to determine whether any correlation could be noted between cross-section areas and relative age of xylem tubes. Next the tube diameters were carefully measured at the base of successive leaf petioles in a number of rosettes. These measurements were made with an eyepiece micrometer graduated to intervals of approximately $3.33 \mu$. Since water conducting efficiency of a given cross-section of capillary tube is a function of the fourth power of its radius (18), the total capacity of each leaf was obtained by getting the sum, (diameter $/ 2)^{4}$, of all its xylem tubes. Mean capacity represents this figure divided by the number of tubes in a given leaf.

The ratio of total capacity to leaf area was also obtained in an effort to see whether it might be correlated with degree of dis- 
section. Leaf area being given in terms of square millimeters, and capacity figured in terms of fourth powers of micromillimeters, the latter have been multiplied by $10^{-12}$ to get both sets in terms of a common unit. For the sake of compactness these figures are multiplied by $10^{8}$ before tabulation, as noted in tables. The foregoing data will be found listed in tables I-VA and plotted in figs. 5 and 6 . Here are also included counts of the number of vein islets per unit area of leaf, taken at mid-distance between margin and midrib and averaged from several counts in each case.

TABLE I

DiAMETER FREQUENCIES OF XYLEM TUBES FOR SUCCESSIVE LEAVES OF SEEDLING PLANT $S A$; EACH UNIT REPRESENTS $3.3 \mu$

\begin{tabular}{|c|c|c|c|c|c|c|c|}
\hline \multirow{2}{*}{ Leaf no. } & \multicolumn{7}{|c|}{ Diameters } \\
\hline & I. 0 & I. 5 & 2.0 & 2.5 & 3.0 & $3 \cdot 5$ & 4.0 \\
\hline 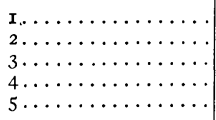 & $\begin{array}{r}\text { I } \\
3 \\
\text { I } 5 \\
2 \\
\text { I }\end{array}$ & $\begin{array}{l}2 \\
9 \\
6 \\
4 \\
4\end{array}$ & $\begin{array}{r}3 \\
\mathrm{I} 2 \\
6 \\
\mathrm{I} 2 \\
\mathrm{I} 6\end{array}$ & $\begin{array}{l}7 \\
9 \\
3 \\
5 \\
7\end{array}$ & $\begin{array}{r}\text { I I } \\
7 \\
2 \\
3 \\
5\end{array}$ & $\begin{array}{l}2^{2} \\
2 \\
\ldots \ldots \ldots \ldots \\
5\end{array} \ldots$ & 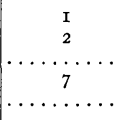 \\
\hline
\end{tabular}

TABLE I A

Other Data For successive Leaves of SEedLING PLANT $S A$

\begin{tabular}{|c|c|c|c|c|c|}
\hline & \multicolumn{5}{|c|}{ Leaf nos. } \\
\hline & I & 2 & 3 & 4 & 5 \\
\hline $\begin{array}{l}\text { Leaf area } \ldots \ldots \ldots \ldots \\
\text { Total xylem capacity } X_{10^{8}} \ldots \ldots \\
\text { Mean xylem capacity } \times 10^{8} \ldots \ldots \\
\frac{\text { Total capacity } \times 10^{8}}{\text { Leaf area }} \ldots \ldots \ldots \ldots\end{array}$ & $\mid \begin{array}{l}\ldots \ldots \ldots \\
\mathbf{1} .37 \\
0.0510 \\
\ldots \ldots \ldots\end{array}$ & $\begin{array}{l}{ }^{250} \\
\text { I. } 5^{2} \\
0.0346 \\
0.006 I\end{array}$ & $\begin{array}{l}125 \\
0.32 \\
0.0101 \\
0.0025\end{array}$ & $\begin{array}{l}\quad 150 \\
2.47 \\
0.0652 \\
0.0165\end{array}$ & $\begin{array}{l}100 \\
0.73 \\
0.0222 \\
0.0073\end{array}$ \\
\hline
\end{tabular}

TABLE II

DiAMETER FREQUENCIES OF XYLEM TUBES FOR SUCCESSIVE LEAVES OF SEEDliNG PLANT $S B$; EACH UNIT REPRESENTS $3 \cdot 3 \mu$

\begin{tabular}{|c|c|c|c|c|c|c|c|c|c|c|c|c|c|c|c|c|}
\hline \multirow{2}{*}{ Leaf no. } & \multicolumn{16}{|c|}{ Diameters } \\
\hline & I.O & I. 5 & 2.0 & 2.5 & 3.0 & $3 \cdot 5$ & 4.0 & $4 \cdot 5$ & 5.0 & $5 \cdot 5$ & 6.0 & 6.5 & 7.0 & $7 \cdot 5$ & 8.0 & 8.5 \\
\hline 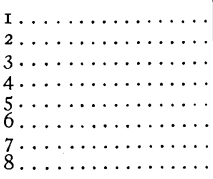 & $\begin{array}{l}\cdots \\
\cdots \\
\cdots \\
1 \\
2 \\
3 \\
\cdots \\
\cdots\end{array}$ & $\begin{array}{r}\cdots \\
\text { I } \\
\text { I } \\
5 \\
9 \\
\text { IO } \\
5 \\
6\end{array}$ & $\begin{array}{r}3 \\
6 \\
8 \\
18 \\
19 \\
7 \\
6 \\
5\end{array}$ & $\begin{array}{r}5 \\
5 \\
12 \\
25 \\
12 \\
9 \\
6 \\
6\end{array}$ & $\begin{array}{r}9 \\
\text { I } 6 \\
\text { 1 } 2 \\
34 \\
15 \\
17 \\
14 \\
14 \\
6\end{array}$ & $\begin{array}{l}7 \\
\text { I0 } \\
\text { I } \\
\text { I } 5 \\
24 \\
\text { I } \\
10 \\
10\end{array}$ & $\begin{array}{r}7 \\
9 \\
\text { I } \\
7 \\
\text { I } 2 \\
7 \\
\text { I0 } \\
\text { I I }\end{array}$ & $\begin{array}{r}2 \\
8 \\
4 \\
\mathrm{II} \\
2 \\
2 \\
4 \\
2\end{array}$ & $\begin{array}{r}5 \\
\text { I I } \\
7 \\
\text { I } 2 \\
\cdots \\
\cdots \cdots \\
4 \\
\cdots\end{array}$ & $\begin{array}{c}6 \\
5 \\
2 \\
I \\
\cdots \\
\cdots \\
I \\
\cdots\end{array}$ & $\begin{array}{r}5 \\
2 \\
3 \\
I \\
\cdots \\
\cdots \\
\cdots \\
\cdots \\
\cdots\end{array}$ & \begin{tabular}{r|} 
I 2 \\
I \\
2 \\
$\cdots$ \\
$\cdots$ \\
$\cdots$ \\
$\cdots$ \\
$\cdots$ \\
$\cdots$
\end{tabular} & $\begin{array}{l}\quad 4 \\
\cdots \\
\cdots \\
\cdots \\
\cdots \\
\cdots \\
\cdots \\
\cdots \\
\cdots\end{array}$ & $\begin{array}{l} \\
6 \\
\cdots \\
\cdots \\
\cdots \\
\cdots \\
\cdots \\
\cdots \\
\cdots\end{array}$ & $\begin{array}{l}\ldots \\
\cdots \\
\cdots \\
\cdots \\
\cdots \\
\cdots \\
\cdots \\
\cdots\end{array}$ & $\begin{array}{c}\text { I } \\
\cdots \cdots \\
\cdots \\
\cdots \\
\cdots \\
\cdots \cdots \\
\cdots \cdots \\
\cdots\end{array}$ \\
\hline
\end{tabular}


TABLE II A

Other DATA FOR SUCCESSIVE LEAVES OF SEEDLING PLANT $S B$

\begin{tabular}{|c|c|c|c|c|c|c|c|c|}
\hline & \multicolumn{8}{|c|}{ Leaf nos. } \\
\hline & I & 2 & 3 & 4 & 5 & 6 & 7 & 8 \\
\hline Leaf area...$\ldots$ & I335 & 896 & I 232 & I 575 & 1058 & 806 & $\cdots \cdots$ & $\cdots$ \\
\hline Leaf dissection . . . . . . & 0.01 & 0.01 & 0.02 & 0.08 & 0.12 & & $\ldots$ & $\ldots$ \\
\hline Total xylem capacity $\times_{10^{8}}$ & 57.24 & I $8.7 \mathrm{I}$ & I6.36 & I7.10 & $7 \cdot 33$ & 4.86 & 8.14 & 4.62 \\
\hline Mean xylem capacity $\times 10^{8}$ & 0.7950 & 0.2529 & $0.224 \mathrm{I}$ & 0.13 I 5 & 0.0772 & 0.0726 & $0.135^{8}$ & 0.1005 \\
\hline Total capacity $\times 10^{8}$ & 0.0428 & 0.0208 & 0.0132 & 0.0108 & 0.0069 & 0.0060 & & $\cdots$ \\
\hline 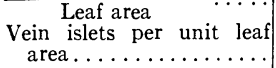 & 10.0420 & 0.0200 & 0.0132 & 0.0100 & 0.0009 & 0.0000 & & $\cdots$ \\
\hline
\end{tabular}

TABLE III

DiAMETER FREQUENCIES OF XYLEM TUBES FOR SUCCESSIVE LEAVES OF SEEDLING PLANT SC; EACH UNIT REPRESENTS $3.3 \mu$

\begin{tabular}{|c|c|c|c|c|c|c|c|c|c|c|c|c|c|}
\hline \multirow{2}{*}{ Leaf no. } & \multicolumn{13}{|c|}{ Diameters } \\
\hline & I.O & I. 5 & 2.0 & 2.5 & 3.0 & 3.5 & 4.0 & $4 \cdot 5$ & 5.0 & $5 \cdot 5$ & 6.0 & 6.5 & 7.0 \\
\hline I $\ldots \ldots \ldots \ldots \ldots$ & $\ldots \ldots$ & 3 & IO & 5 & I 5 & 7 & I 6 & 2 & I 5 & 2 & 5 & I & $\ldots \ldots$ \\
\hline $2 \ldots \ldots \ldots \ldots \ldots$ & $\ldots \ldots$ & 5 & 17 & I 4 & 39 & 21 & 34 & IO & 28 & 8 & I3 & 4 & $\ldots \ldots$ \\
\hline $3 \ldots \ldots \ldots \ldots \ldots$ & I & 2 & I I & 4 & 16 & I 7 & 9 & IO & I3 & 6 & 3 & 2 & I \\
\hline $4 \ldots$ & $\ldots \ldots$ & 6 & 4 & 8 & 24 & 5 & 20 & 4 & I 7 & $\mathbf{I}$ & 2 & $\ldots \ldots$ & $\ldots \ldots$ \\
\hline$\ldots \ldots \ldots$ & 2 & 3 & I4 & I I & 27 & I6 & I I & 6 & 5 & $\ldots \ldots$ & $\ldots \ldots$ & $\ldots \ldots$ & $\ldots \ldots$ \\
\hline$\ldots \ldots \ldots$ & $\ldots \ldots$ & 3 & I 2 & Io & I 8 & I 5 & I4 & 6 & 6 & $\ldots \ldots$ & $\ldots \ldots$ & $\ldots$ & $\ldots$ \\
\hline $7 \ldots \ldots$ & $\ldots \ldots$ & 5 & I I & I3 & I6 & 16 & 20 & 4 & IO & 3 & 2 & $\ldots$ & $\ldots \ldots$ \\
\hline $8 \ldots$ & 2 & I0 & 15 & IO & 23 & 20 & I 7 & 6 & 4 & I & $\ldots \ldots$ & $\ldots \ldots$ & $\ldots \ldots$ \\
\hline $9 \ldots$ & 4 & 6 & IO & I 3 & 29 & I 8 & I & I & $\ldots \ldots$ & $\ldots \ldots$ & $\ldots \ldots$ & $\ldots$ & $\ldots$ \\
\hline го. $\ldots \ldots \ldots \ldots \ldots$ & 4 & 9 & I I & I6 & 19 & 6 & 3 & $\ldots \ldots$ & $\ldots \ldots$ & $\ldots \ldots$ & $\ldots \ldots$ & $\ldots \ldots$ & $\ldots \ldots$ \\
\hline II $\ldots \ldots \ldots \ldots \ldots$ & 4 & 8 & I I & I 7 & I 5 & I4 & 5 & 2 & $\ldots \ldots$ & $\ldots \ldots$ & $\cdots \cdots$ & $\ldots$ & $\ldots \ldots$ \\
\hline r $2 \ldots \ldots \ldots \ldots \ldots$ & 2 & 9 & IO & I4 & IO & 7 & I 3 & 3 & I & $\cdots \cdots$ & $\cdots \cdots$ & $\cdots$ & $\ldots \ldots$ \\
\hline
\end{tabular}

TABLE IV

DIAMETER FREQUENCIES OF XYLEM TUBES FOR SUCCESSIVE LEAVES UF SEEILLING PLANT $S D$; EACH UNIT REPRESENTS $3.3 \mu$

\begin{tabular}{|c|c|c|c|c|c|c|c|c|c|c|c|}
\hline \multirow{2}{*}{ Leaf no. } & \multicolumn{11}{|c|}{ Diameters } \\
\hline & I , O & I $\cdot 5$ & 2.0 & 2.5 & 3.0 & $3 \cdot 5$ & 4.0 & $4 \cdot 5$ & 5.0 & $5 \cdot 5$ & 6.0 \\
\hline $5 \ldots \ldots \ldots \ldots \ldots$ & 3 & I 2 & I4 & 9 & I6 & 4 & 3 & $\ldots \ldots$ & $\ldots \ldots$ & $\ldots \ldots$ & $\ldots \ldots$ \\
\hline $6 \ldots \ldots \ldots \ldots$ & 2 & IO & 22 & I 7 & I 8 & 6 & 2 & $\ldots \ldots$ & $\ldots \ldots$ & $\ldots \ldots$ & $\ldots \ldots$ \\
\hline $7 \ldots \ldots \ldots \ldots \ldots$ & $\mathbf{I}$ & I I & $3 I$ & 9 & I3 & 5 & $\ldots \ldots$ & $\ldots \ldots$ & $\ldots \ldots$ & $\ldots \ldots$ & $\ldots \ldots$ \\
\hline $8 \ldots \ldots \ldots \ldots$ & $\ldots \ldots$ & I5 & I7 & I 2 & 22 & I4 & Io & 2 & $\ldots \ldots$ & $\ldots \ldots$ & $\ldots \ldots$ \\
\hline $9 \ldots \ldots \ldots \ldots \ldots$ & I. & 9 & 34 & I3 & 26 & 6 & 4 & $\ldots \ldots$ & $\ldots \ldots$ & $\ldots \ldots$ & $\ldots \ldots$ \\
\hline ro $\ldots \ldots \ldots \ldots \ldots$ & 2 & 8 & 16 & I 8 & IO & 4 & 3 & $\ldots \ldots$ & $\ldots \ldots$ & $\ldots \ldots$ & $\ldots \ldots$ \\
\hline II $\ldots \ldots \ldots \ldots \ldots$ & 4 & IO & 20 & II & I3 & 4 & I & $\ldots \ldots$ & $\ldots \ldots$ & $\ldots \ldots$ & $\ldots \ldots$ \\
\hline I $2 \ldots \ldots \ldots \ldots$ & 2 & 3 & II & 6 & $2 I$ & 7 & 6 & $\ldots \ldots$ & $\ldots \ldots$ & $\ldots \ldots$ & $\ldots \ldots$ \\
\hline $13 \ldots \ldots \ldots$ & 4 & 3 & 6 & 6 & I5 & I 2 & 9 & 5 & 5 & 3 & $\ldots \ldots$ \\
\hline I $4 \ldots \ldots$ & $\ldots \ldots$ & 2 & 5 & 9 & I I & I I & 14 & 5 & 5 & $\ldots \ldots$ & $\ldots \ldots$ \\
\hline I $5 \ldots \ldots \ldots$ & $\ldots \ldots$ & I & 6 & 9 & I6 & 9 & I I & 4 & 7 & I & I \\
\hline I6....... & $\ldots \ldots$ & 2 & 7 & 8 & I 7 & 8 & I 3 & $\ldots \ldots$ & 7 & $\ldots \ldots$ & $\ldots \ldots$ \\
\hline I $7 \ldots \ldots \ldots$ & I & $\ldots \ldots$ & I 2 & 3 & I I & I 3 & 9 & $\ldots \ldots$ & 3 & $\ldots \ldots$ & $\ldots \ldots$ \\
\hline $18 \ldots \ldots \ldots$ & I & 2 & IO & 5 & IO & 5 & 8 & 3 & $\ldots \ldots$ & $\ldots \ldots$ & $\ldots \ldots$ \\
\hline
\end{tabular}



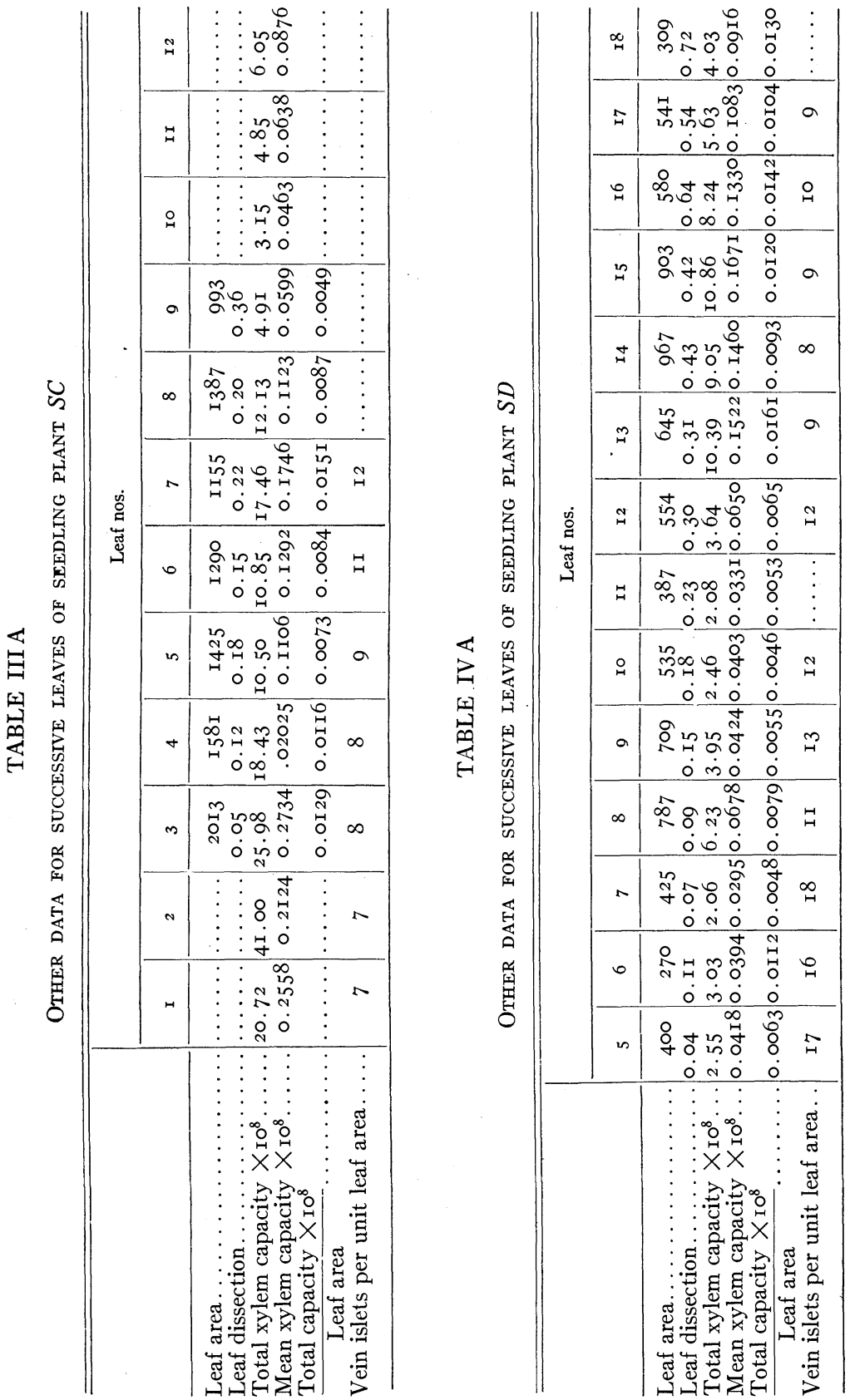
TABLE V

DiAMETER FREQUENCIES OF XYLEM TUBES FOR SUCCESSIVE LEAVES OF REJUVENATED PLANT $R$; EACH UNIT REPRESENTS $3 \cdot 3 \mu$

\begin{tabular}{|c|c|c|c|c|c|c|c|c|c|c|c|c|c|c|c|c|}
\hline \multirow{2}{*}{ Leaf no. } & \multicolumn{16}{|c|}{ Diameters } \\
\hline & I.O & I. 5 & 2.0 & $2 \cdot 5$ & 3.0 & $3 \cdot 5$ & 4.0 & $4 \cdot 5$ & 5.0 & $5 \cdot 5$ & 6.0 & 6.5 & 7.0 & $7 \cdot 5$ & 8.0 & 8.5 \\
\hline $2 \ldots \ldots \ldots$ & $\ldots$. & 2 & I3 & I3 & I9 & 5 & 8 & 6 & I3 & 7 & I 2 & 3 & 9 & 4 & 6 & I \\
\hline $4 \ldots \ldots \ldots$ & $\ldots$ & 8 & I 8 & I0 & 32 & II & 25 & 8 & I7 & 5 & 13 & 2 & IO & 2 & I & $\ldots$ \\
\hline $6 \ldots \ldots \ldots \ldots \ldots$ & $\ldots$ & 5 & IO & 7 & 22 & I4 & 24 & I 5 & 25 & II & 6 & 2 & $\ldots$ & $\ldots$ & $\ldots$ & $\ldots$ \\
\hline $8 \ldots$ & $I$ & 4 & IO & Io & I 6 & I 4 & 20 & I I & I5 & 7 & 8 & $\ldots$ & I & $\ldots$ & $\ldots$ & $\ldots$ \\
\hline го.............. & $\ldots$ & 9 & 23 & I4 & I3 & 12 & I 7 & I 5 & I6 & 5 & 3 & $\ldots$ & $\ldots$ & $\ldots$ & $\ldots$ & $\ldots$ \\
\hline I $2 \ldots \ldots \ldots \ldots \ldots$ & $\ldots$ & 3 & 6 & 9 & II & 5 & I 2 & 3 & I6 & 7 & 6 & $\ldots$ & 3 & $\ldots$ & $\ldots$ & $\ldots$ \\
\hline I $4 \ldots \ldots \ldots \ldots$ & $\ldots$ & $\ldots$ & 7 & 7 & I I & 5 & 9 & 8 & IO & 3 & 8 & 3 & 3 & $\ldots$ & $\cdots$ & $\ldots$ \\
\hline г6 $\ldots \ldots \ldots \ldots \ldots$ & $\cdots$ & $\cdots$ & 6 & 4 & II & I & IO & 3 & 6 & 5 & 7 & 3 & $\cdots$ & $\cdots$ & $\cdots$ & $\cdots$ \\
\hline
\end{tabular}

For comparative purposes, distortion figures have been worked out so far as trustworthy available data permit. These are based upon changes produced by senescence (original), depauperation (2), and moisture (20). It is to be regretted that the only established facts with regard to light are its axiomatic effects upon leaf position and the effect of darkness in stimulating the production of internodes. The method used in working out these figures should be apparent from inspection, and can be found adequately discussed by THOMPSON (19).

In addition to these methods, microchemical studies were made throughout the summer of I92 I on tissues of $T$. vulgare plants in all stages of senescence and rejuvenescence.

RESULTS.-In general it will be noted that the percentage of dissection in various plants of $T$. vulgare tends to rise at a uniform rate. Studies of second year flowering plants indicate that after a value of 0.5 is attained, the degree of dissection fluctuates about that as an approximate mean until late in the flowering period. Then, as previously noted, if many leaves have been produced, the curve may rise to a higher value.

With respect to $T$. laevigatum, fewer determinations are at hand and none are listed. All that have been made indicate that the rate of increase of dissection is not so rapid, but continues until a value of about 0.8 is reached, fluctuating about this value during the adult period proper.

That the increase in degree of dissection is not merely a veiled expression of progressive decrease in leaf area is evident from fig. 5 . 


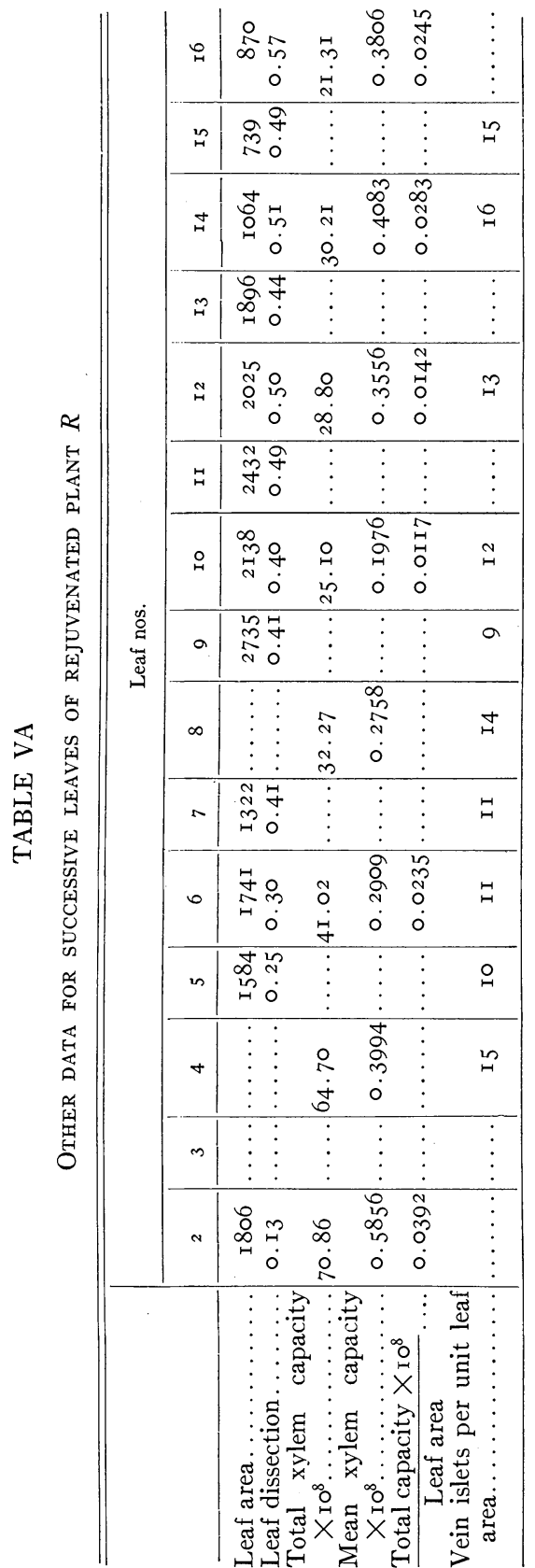

It will be noted that absolute leaf area decreases rather uniformly in $S C$, a seedling plant grown under apparently favorable conditions. On the other hand, $S D$, a seedling that started under hard conditions (tight, dry clay), shows a gradual uniform increase. Of course these facts are established easily by familiar observation, but they are mentioned here to show the positive necessity of studies based upon field material growing under varying natural conditions. Not only here, but in connection with studies of xylem capacity, very erroneous ideas of senescent correlation might have been obtained by limiting studies to uniformly grown culture material, as a glance at the graphs will show.

Total and mean xylem duct capacity measured and computed as stated show a seeming correlation with degree of senescence in the cases of $S B$ and $S C$ seedlings, and somewhat less in the case of $R$, a secondary rosette. The possibility that this correlation is real, however, is quite upset by data on the depauperate seedlings $S A$ and $S D$. 




FIG. 5.-Abscissae represent successive leaves of various rosettes, ordinates the respective characters measured in each set of graphs; $S$, seedlings; $R$, rejuvenated rosette. 


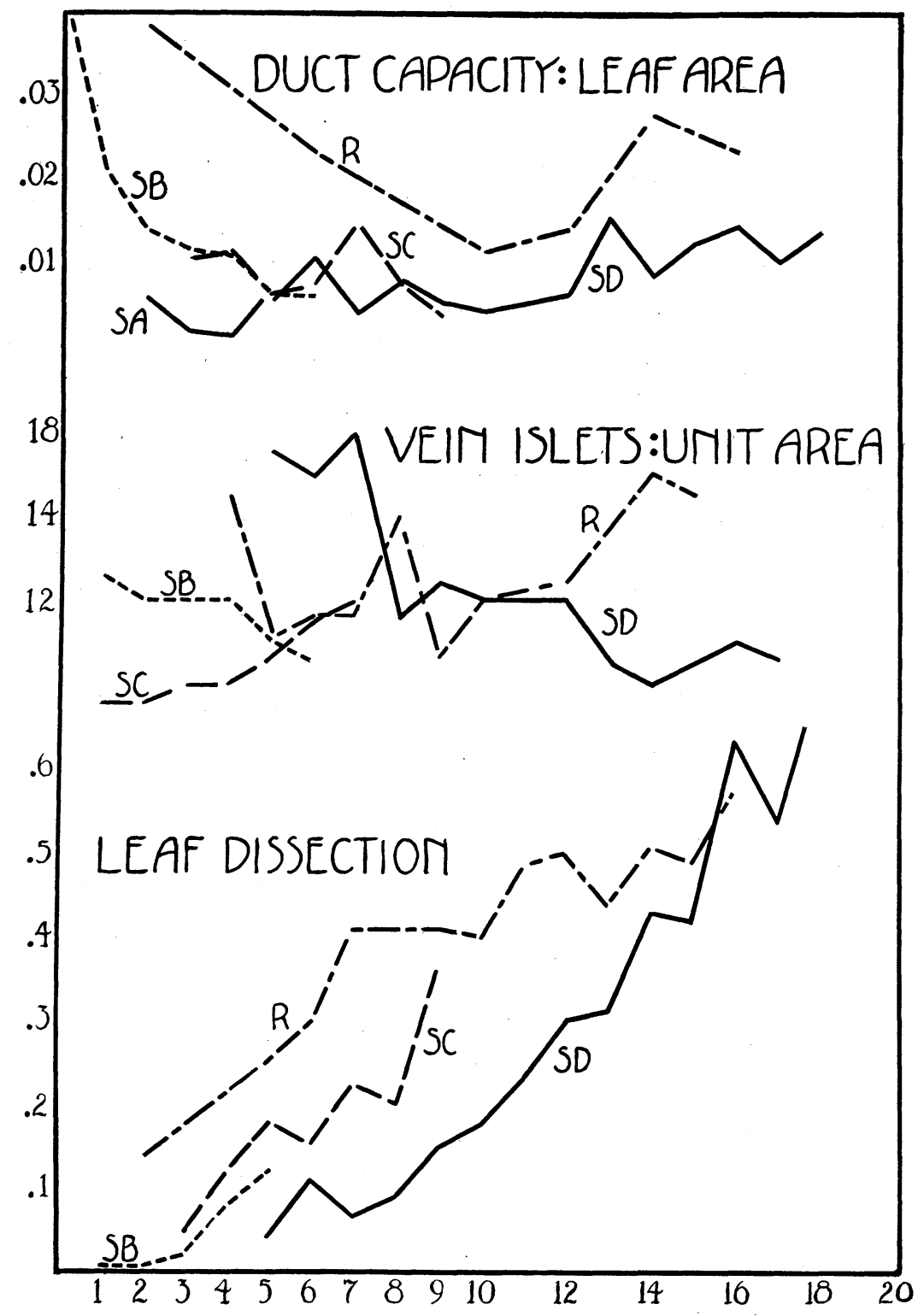

FIG. 6.-See explanation of fig. 5 
Both of the latter showed steady increase in leaf dissection, although through an accident to the print of $S A$ its dissection data could not be worked out. As with leaf area, therefore, total and mean duct capacity are plainly influenced by some factor other than senescence, doubtless environmental.

Essentially the same statement may be made with respect to the ratio (duct capacity / leaf area) and to BENEDict's ( $\mathbf{r}$ ) criterion (vein islets / unit leaf area), from which we may at least
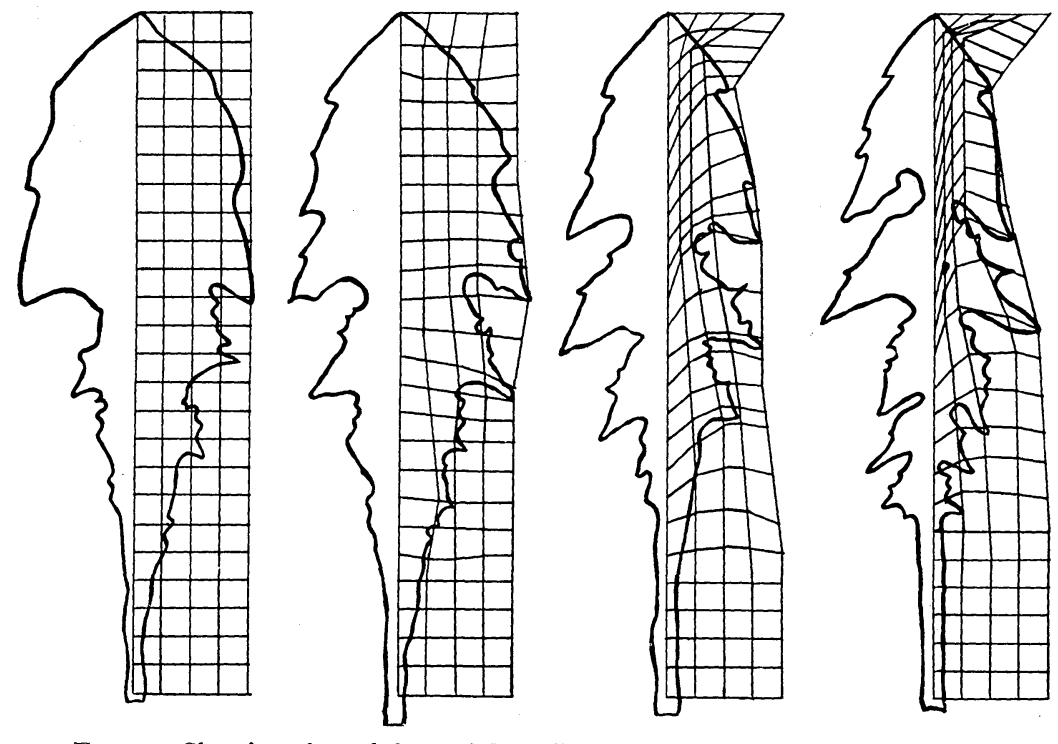

FIG. 7.-Showing, from left to right, effect of senescence on successive leaves of rosette; coordinates run through homologous points in each case.

with safety conclude that the criterion for senescence in Vitis certainly is no criterion in $T$. vulgare. Since the completion of the present work, ENSIGN (6) has shown a similar lack of correlation between vein islet area and age in several genera, including even Vitis.

Distortion figures for senescent change (fig. 7) are chiefly of value in showing that the successive sets of forms in a rosette can be homologized. They likewise show, what seems clear from inspection of ordinary leaves, that the increase in degree of dissection is the result of an increasing degree of inhibition of the tip 
segment and of expression of the following segments. Fig. 8, derived from BONNIER's (2) transplanting experiment, shows in leaves of corresponding age a rather uniform reduction of coordinates throughout; that is, more or less symmetrical reduction of leaf size. Numerous observations of the writer upon potted specimens of the same age, growing side by side but in pots of different

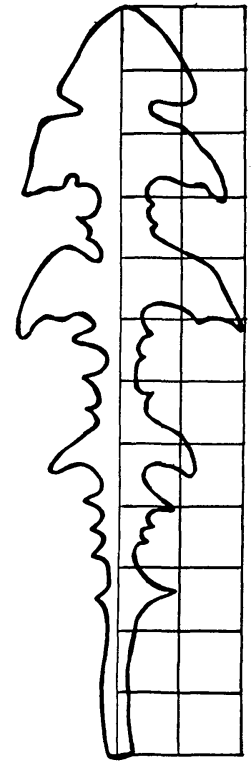

FIG. 8

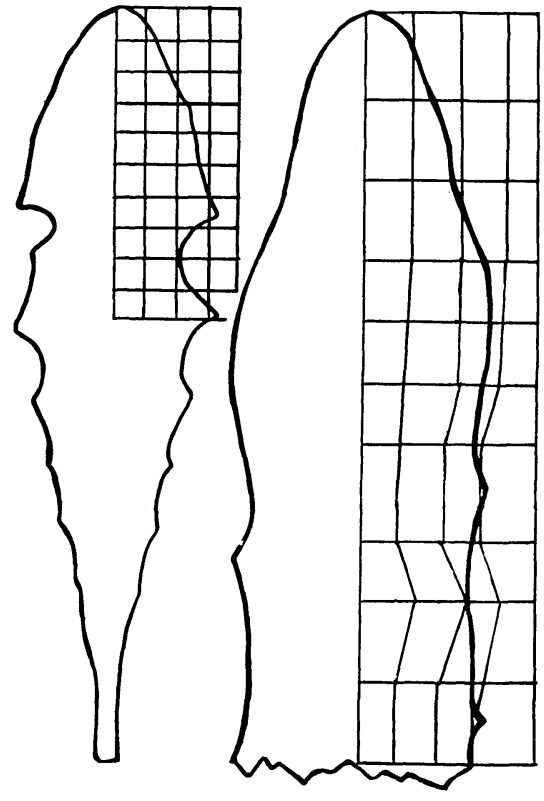

FIG. 9

Fiss. 8, 9.-Fig. 8, showing relatively uniform dwarfing brought about by alpine conditions (right) as compared with lowland (left); after Bonnier; fig. 9, showing great increase, particularly in length, produced by saturated (right) as compared with somewhat dry air (left); after WIESNER.

sizes, indicate that symmetrical dwarfing (depauperation) does occur without greatly influencing leaf form. Under such conditions the depauperate specimens produce markedly fewer leaves, and as a consequence may be ready to bloom before dissection has progressed quite so far as in normal thrifty specimens. Facts of this nature must be thoroughly understood before "alpine" forms of Taraxacum are pronounced distinct species, or the generalization 
drawn that unfavorable conditions per se tend to produce entire leaves.

WIESNER's figures of the effect of increased moisture, while in general borne out by the writer's observations, must be accepted with reserve upon one detail. It is by no means certain that the slight degree of dissection visible in the smaller dry-air leaves can be attributed to environmental factors (fig. 9). As previously noted, WIESNER merely indicates that both sets of leaves were from the same parent plant. It frequently happens that multicipital branches of various ages occur upon the same taproot (fig. 4). Experiments show that the moist-air leaf which he figures is the typical form obtained by placing a juvenile rosette with undissected leaves beneath a belljar. Furthermore, the driest conditions under which Taraxacum will grow do not prevent the normal sequence of entire leaves followed by more dissected ones, although it is quite conceivable that they may affect the rate of senescence. In the last place, if a mature rosette be placed in saturated air, dissected leaves are produced until rejuvenation occurs. The distortion figures show, bearing these reservations in mind, that saturated air causes production of leaves that are larger and considerably longer than those grown in drier air.

Microchemical tests upon plants of various ages and degrees of leaf dissection have revealed a number of points of physiological interest, of which only one will be mentioned here. In all plants tested, from whatever habitat, juvenile leaf form was accompanied by high nitrate tests and little reserve carbohydrate. This is not unique; unpublished studies of ECKERSON, working with KRAUS at Wisconsin, show that leaf dissection of tomato is increased by scarcity of nitrate as compared with carbohydrate. It is moreover of interest to recall LoNG's (13) finding, that inner leaves of Taraxacum rosettes are richer in photosynthate than outer.

In conclusion, it is to be noted that a rather extensive survey of published species descriptions reveals that a considerable number of them will fit variants of either $T$. vulgare or $T$. laevigatum caused by the interplay of the factors that have been described. While this statement is presented upon the writer's responsibility, without detailed data, it may readily be verified in one case by an inspection 
of the figure and description of Leontodon latilobum given in BRITTON and BRown's Illustrated flora, $2 \mathrm{~d}$ ed. It is clearly a juvenile rosette and hence not a valid type for comparison. Possibly it is flowering in the juvenile condition because of an autumnal start followed by a winter rest, as previously described. It certainly may be a legitimate distinct species, and so may a great many others, but it is not too much to suggest that taraxacologists have been ignoring grave sources of error, and to insist that future diagnoses be placed upon a satisfactory physiological basis.

\section{Summary}

I. Senescent and rejuvenescent change in leaf form is a prime factor in producing variations in Taraxacum vulgare and T. laevigatum.

2. Senescence produces a steadily increasing degree of dissection, and frequently of hairiness; rejuvenescence restores the unsegmented juvenile seedling leaf form.

3. These changes are independent of changes in (a) absolute leaf area, $(b)$ total xylem duct capacity in successive leaves, $(c)$ mean xylem duct capacity in successive leaves, $(d)$ ratio of total capacity to leaf area, and $(e)$ number of vein islets per unit area of leaf.

4. Senescence, however, is accompanied by a marked increase in carbohydrate-nitrogen ratio and rejuvenescence by its abrupt decrease.

5. Environmental factors are of secondary importance in so far as studied. Moist atmosphere causes elongation of leaves. Time of seeding may govern time of flowering and rejuvenation; this in turn may affect degree of dissection in plants at flowering time.

6. Pure stands of distinctive variants in certain cases may be explained by environmental control of seed germination time.

7. The majority of so-called specific characters in Taraxacum are subject to extreme fluctuation.

8. These fluctuations in other than leaf characters are in some cases due to senescent change, in others to environmental factors, but mostly to causes not known.

9. Such fluctuations, together with senescent and ecological changes in leaf form, are potent enough when working upon the 
two common species to produce phenotypes duplicating many socalled species.

Io. Many such species may be valid, but so far the physiological evidence has not been obtained.

University of Chicago

\section{LITERATURE CITED}

I. BENEDICT, H. M., Senile changes in leaves of Vitis vulpina L. and certain other plants. Mem. N.Y. Agric. Exp. Sta. 7. Ithaca. I9r 5.

2. Bonnier, G., Recherches experimentales sur l'adaptation des plantes au climat alpin. Ann. Soc. Nat. Bot. VII. 20:217-360. I895.

3. Brenner, M., Varietates novae Taraxaci officinalis. Medd. Soc. Fauna Flor. Fennica 32:96-99. r9o6.

4. Caspary, R., Eine Wruke (Brassica napus L.) mit Laubsprossen auf knolligem Wurzelausschlag. Schrift. Phys.-Ökon. Gesells. Königsberg 14: IO9-II2. I873.

5. Cowles, H. C., Textbook of ecology. Chicago. igri.

6. ENSIGN, M. R., Area of vein islets in certain leaves as an age determinant. Amer. Jour. Bot. 8:433-44I. I92 I.

7. Fernald, M. L., Taraxacum palustre in America. Rhodora 4:I55-I 57. I 902 .

8. Frank, A. B., Lehrbuch der Botanik. Leipsic. I892.

9. Goebel, K. Organographie der Pflanzen. Jena. I9or.

ı. Handel-Mazetti, H. von, Monographie der Gattung Taraxacum. Wien. I907.

II. Ihne, E., and Schweter, I., Hermann Hoffman. Ber. Deutsch. Bot. Gesells. 10:(20). I892.

12. Index Kewensis. Supplement 4. rgro.

13. Long, F. L., The quantitative determination of photosynthetic activity in plants. Physiol. Researches 2:277-300. I9I9.

14. Morgan, T. H., Evolution and adaptation. New York. I908.

15. Miyake, K., Über das Wachstum des Blütenschaftes von Taraxacum. Beih. Bot. Centr. 16:403-414. I904.

r6. Schorbatow, L., Parthenogenese und Apogame Entwicklung bei den Blutenpflanzen. Entwicklungsgeschichtliche Studien an Taraxacum officinale Wigg. Trav. Soc. Nat. Univ. Imp. Khark. 45: I5-55. I9II-I9I 2.

17. Stork, H. E., Studies in the genus Taraxacum. Bull. Torr. Bot. Club 47: I99-210. I920.

18. Strasburger, E., Jost, L., Schenk, H., Karsten, G., Lehrbuch der Botanik für Hochschulen. Jena. ı9ıо.

19. Thompson, D. A. W., Growth and form. Cambridge. I917.

20. Wiesner, J., Biologie der Pflanzen. Wien. i889. 